ISSN 1678-3921

Journal homepage: www.embrapa.br/pab

For manuscript submission and journal contents, access: www.scielo.br/pab

\section{Marjoram phytomass at harvest intervals in summer and winter transplants}

\begin{abstract}
The objective of this work was to determine the harvest interval for phytomass production of marjoram (Origanum majorana) in summer and winter transplants. Two independent experiments were performed in offground cultivation: one with a summer and another with a winter transplant, in a completely randomized design with five harvest intervals $(30,45,60,72$, and 90 days) and four replicates. The fresh and dry masses of leaves, branches, and aerial part were determined. For each plant, the production accumulated in the harvests was calculated as affected by days after the transplant. The fresh matter mass of the leaves was higher at the intervals of 60 and 90 days, in the summer transplant, and of 72 and 90 days, in the winter transplant. Harvesting at intervals of 60 days in the summer transplant and of 72 days in the winter transplant are appropriate for marjoram phytomass production.
\end{abstract}

Index terms: Origanum majorana, phytomass production, off-ground cultivation.

\section{Fitomassa de manjerona em intervalos de colheita em transplantes no verão e no inverno}

Resumo - O objetivo deste trabalho foi determinar o intervalo de colheita para produção de fitomassa de manjerona (Origanum majorana), em transplantes no verão e no inverno. Foram realizados dois experimentos independentes em cultivo fora do solo: um com transplante no verão e outro no inverno, em delineamento inteiramente casualizado, com cinco intervalos de colheita $(30,45,60,72$ e 90 dias) e quatro repetições. Foram determinadas as massas de matéria fresca e seca de folhas, ramos e parte aérea. Para cada planta, foi calculada a produção acumulada nas colheitas em função dos dias após o transplante. A massa de matéria fresca de folhas foi superior nos intervalos de 60 e 90 dias, no transplante de verão, e de 72 e 90 dias, no transplante de inverno. Colheitas em intervalos de 60 dias, no transplante de verão, e de 72 dias, no transplante de inverno, são apropriadas para produção de fitomassa de manjerona.

Termos para indexação: Origanum majorana, produção de fitomassa, cultivo fora do solo.

\section{Introduction}

Among the most consumed aromatic plant species in Brazil, marjoram (Origanum majorana L.) stands out, with its leaves, in the fresh form, being its most used part (Pereira \& Santos, 2013). Marjoram has medicinal characteristics of interest to the pharmaceutical, herbal, and food industries, with antibacterial (Joshi et al., 2009), antifungal (Leeja \& Thoppil, 2007), antioxidant (Mossa \& Nawwar, 2011; Roby 
et al., 2013), antispasmodic, and arterial vasodilator (Jelali et al., 2011) activities.

Plant production is favored by protected cultivation, which allows the management of climatic factors, such as air temperature and humidity, solar radiation, and wind (Santos et al., 2010). That system, in which plants can be cultivated off-ground, using a nutrient solution for fertigation (Sabir \& Singh, 2013), is promising and viable for the cultivation of medicinal plants (Maia et al., 2014).

For condiment, medicinal, and aromatic plants, the influence of the harvest interval on crop phytomass has been investigated. May et al. (2010), for example, verified a greater accumulation of dry matter in the aerial part of rosemary (Rosmarinus officinalis L.) at longer harvest intervals. The same was observed by May et al. (2008) for lemongrass (Cymbopogon flexuosus Stapf.). However, Sabra et al. (2018) reported an increase in the phy tomass of Indian borage [Plectranthus amboinicus (Lour.) Spreng.] only until the third harvest, six months after transplantation, followed by a subsequent decrease. Therefore, these researches show different responses of plants to harvest intervals, indicating the importance of studying the influence of this type of management on each species, in order to expand knowledge and facilitate the programming of cultivation, aiming at a greater productivity.

Another factor that influences plant phytomass is the time of transplantation. Luz et al. (2014) found a higher plant height and greater fresh matter weight for basil (Ocimum basilicum L.) leaves transplanted in summer, when compared with those transplanted in spring. For the medicinal species fennel (Foeniculum vulgare Mill.), grown in Egypt, in the Northern hemisphere, sowing on October 7 (autumn) resulted in a greater vegetative growth and productivity (fruits per plant) than on September 15 (late summer) and November 1 (autumn) (Selim et al., 2013). Therefore, it can be assumed that the harvest intervals and the season of the transplant influence the phytomass of marjoram plants.

The objective of this work was to determine the harvest interval for phytomass production of marjoram in summer and winter transplants.

\section{Materials and Methods}

Two independent experiments with marjoram were conducted in an off-ground cultivation system, in a $115 \mathrm{~m}^{2}(5 \times 23 \mathrm{~m})$ sheltered environment, covered with $150 \mu \mathrm{m}$ anti-UV additive polyethylene, at the Department of Crop Science of Universidade Federal de Santa Maria, located in the state of Rio Grande do Sul, Brazil. The first experiment was installed on December 28, 2017 (summer transplant), and conducted until December 23, 2018, totaling 12 months, and the second was installed on June 28, 2018 (winter transplant), continuing until June 23, 2019, also totaling 12 months.

During the cultivation period, the temperature inside the shelter was recorded by a digital data logger, with a $0.1^{\circ} \mathrm{C}$ resolution and $0.5^{\circ} \mathrm{C}$ accuracy, installed on site. Solar radiation was registered at an automatic meteorological station, belonging to the eighth district of meteorology of Instituto Nacional de Meteorologia, located $300 \mathrm{~m}$ from the cultivation environment (Figure 1).

Fertigation was carried out using dripping tapes, positioned on the top of the used pots, with one dripper per plant. A nutrient solution was prepared and stored in $500 \mathrm{~L}$ polypropylene boxes and, then, supplied to the plants using a motor pump controlled by an hour programmer. The used nutrient solution had the following composition: $9.68 \mathrm{mmol} \mathrm{L}^{-1} \mathrm{NO}_{3}^{-}, 0.88$ $\mathrm{mmol} \mathrm{L}-1 \mathrm{NH}_{4}^{+}, 1.36 \mathrm{mmol} \mathrm{L}-1 \mathrm{H}_{2} \mathrm{PO}_{4}^{-}, 5.00 \mathrm{mmol}$ $\mathrm{L}^{-1} \mathrm{~K}^{+}, 2.58 \mathrm{Ca}^{2+}, 2.00 \mathrm{mmol} \mathrm{L} \mathrm{L}^{-1} \mathrm{Mg}^{2+}$, and 2.00 mmol L-1 $\mathrm{SO}_{4}^{-}$. The supplied micronutrients were: $0.03 \mathrm{mg} \mathrm{L}^{-1} \mathrm{Mo}, 0.26 \mathrm{mg} \mathrm{L}^{-1} \mathrm{~B}, 0.06 \mathrm{mg} \mathrm{L}^{-1} \mathrm{Cu}$, $0.50 \mathrm{mg} \mathrm{L}^{-1} \mathrm{Mn}, 0.22 \mathrm{mg} \mathrm{L}^{-1} \mathrm{Zn}$, and $1.0 \mathrm{mg} \mathrm{L}^{-1}$ $\mathrm{Fe}$ in chelated form. This nutrient solution was adapted for the studied culture, being adjusted for the following fertilizers: $\mathrm{KNO}_{3}$, calcium nitrate $\left(\mathrm{Ca}\left(\mathrm{NO}_{3}\right)_{2}\right), \mathrm{MgSO}_{4}$, and $\mathrm{NH}_{4} \mathrm{H}_{2} \mathrm{PO}_{4}$ (Mambri et al., 2018). The macronutrients were supplied by means of potassium nitrate, monobasic ammonium phosphate, calcium nitrate (Calcinit Yara Tera, Yara Brasil S.A, Porto Alegre, RS, Brazil), and magnesium sulfate. The electrical conductivity of the nutrient solution was monitored weekly, using a portable conductivity meter, and corrected with the addition of aliquots of a new solution whenever necessary, keeping the value at $1.84 \mathrm{dS} \mathrm{m}^{-1}$.

The marjoram seedlings used in the first experiment (transplant in summer) were obtained 
from a commercial store in the municipality of Santa Maria. The marjoram seedlings used in the second experiment (transplant in winter) were produced at the site of the experiment, using parent plants grown in off-ground cultivation in greenhouses. For this, $4 \mathrm{~cm}$ cuttings from the tips of the branches of the plants were used, leaving two expanded leaves at the end. These were put in contact with the powdered indolebutyric acid hormone at $0.1 \%$ concentration, and then placed in Styrofoam trays containing commercial substrate. The trays with the seedlings were placed on a bench, inside the greenhouse, with sprinkler-type irrigation. Seedling transplantation was performed after 45 days, when the root system was well formed.

In both experiments, the seedlings were transplanted into white $3 \mathrm{dm}^{3}$ polyethylene pots, filled with the MecPlant commercial substrate (MecPlant Company, Telêmaco Borba, PR, Brazil), composed of pine bark, vermiculite, acidity concealer, and macronutrients. The pots were placed on benches $1.10 \mathrm{~m}$ wide, $4 \mathrm{~m}$ long, and $80 \mathrm{~cm}$ high in relation to the concrete floor. Two benches were used in each experiment. In each bench, 44 pots were placed, resulting in 88 pots and, consequently, in 88 plants in each experiment. In order to standardize the experiments and allow the same growth conditions for the plants, the treatments (harvest intervals) were separated by borders made up of plants, which were pruned every 30 days. In the treatment plots, the two central plants were used as replicates and the two side plants were used as treatment borders. Therefore, the evaluations were carried out on 20 plants per experiment, with the other ones being considered as either borders of the experiment or of the treatments.

A completely randomized design was used, with five treatments, which are the intervals of $30,45,60$, 72 , and 90 days between successive harvests from the date of transplantation, with four replicates; each replicate was equivalent to one plant. The harvests (cuttings of the plants) were carried out at a height of $7 \mathrm{~cm}$ in relation to the base of the plant, in order

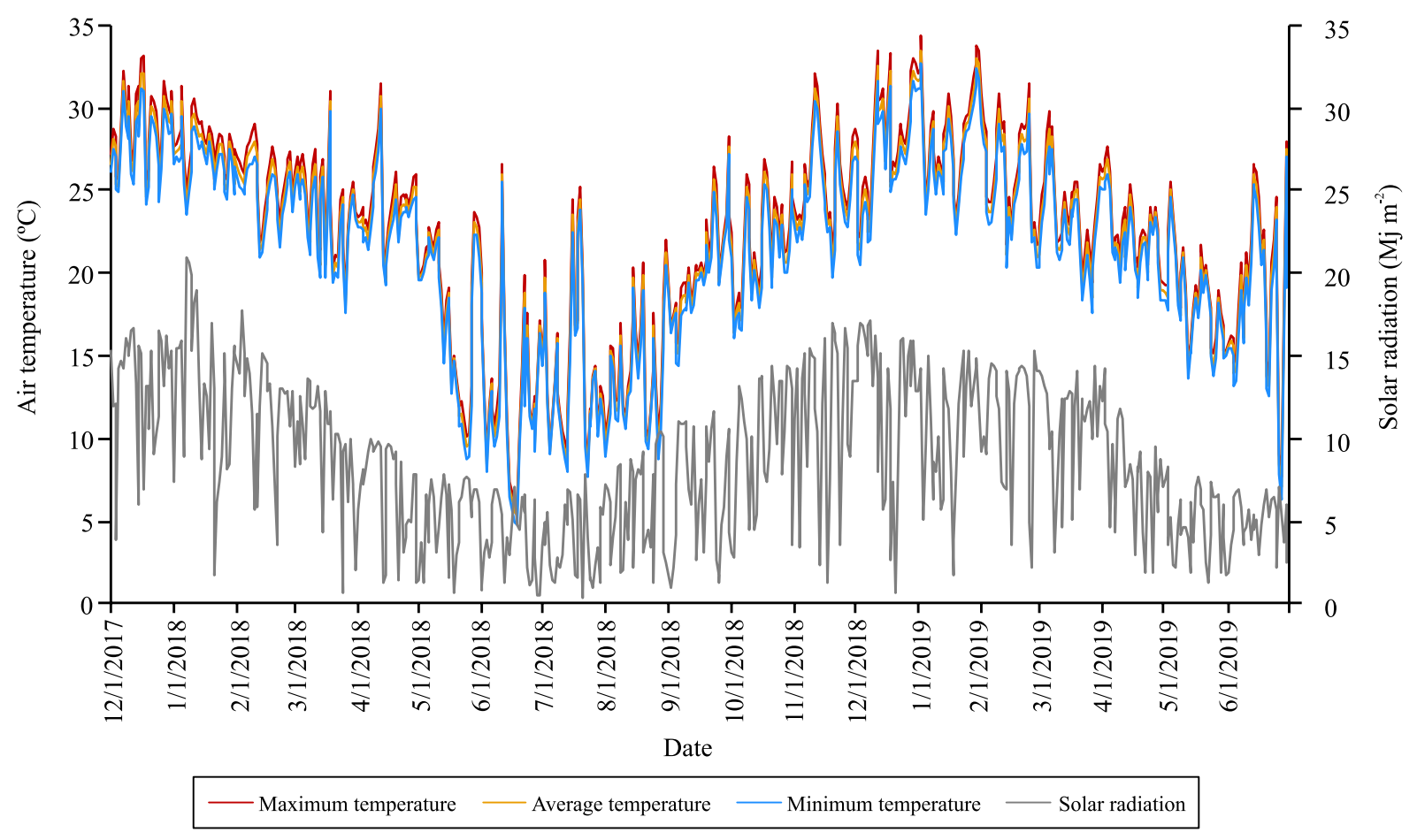

Figure 1. Maximum, average, and minimum air temperatures and solar radiation inside the greenhouse, from December 2017 to June 2019, in the municipality of Santa Maria, in the state of Rio Grande do Sul, Brazil. 
to allow the regrowth of the branches. Masses were determined for: fresh matter of leaves, branches, and aerial part (leaves + branches), in gram per plant; and dry matter of leaves, branches, and aerial part (leaves + branches), also in gram per plant, after the samples were dried in a forced-air ventilation oven, at $65^{\circ} \mathrm{C}$, until constant weight.

At 12 months after transplantation, the last evaluation of all intervals between harvests was carried out. In the summer experiment, the last harvest was on December 23, 2018, and in the winter experiment, on June 23, 2019. At the end of the experiments, 12 harvests were obtained in the 30day interval, eight harvests in the 45-day interval, six harvests in the 60-day interval, five harvests in the 72-day interval, and four harvests in the 90-day interval. The masses of each harvest, for each one of the plants (replicates), were added to obtain the accumulated production.

For each variable (masses of fresh and dry matter of leaves, branches, and aerial part), the normality of errors was verified by Shapiro-Wilk's test and the homogeneity of residual variances, by Bartlett's test. A regression analysis was also performed for quantitative variables. Statistical analyzes were carried out with the aid of the Action (Equipe Estatcamp, 2014) and SISVAR, version 5.7 (Ferreira, 2014), software.

\section{Results and Discussion}

The regression analysis between the accumulated mass production of marjoram and the harvest interval showed the highest values were obtained at the longest intervals $(60,72$, and 90 days) in the summer transplant (Figure 2).

At longer intervals, the plants have a greater recovery time between harvests, which increases the potential of mass production per day, resulting in a higher accumulated production at the end of the cycle. Earlier harvests (at shorter intervals) are harmful to plants, as they are still in the stage of development and adaptation, reducing their growth and weakening them (Ibrahim et al., 2012).

The regression analysis between the accumulated mass production of marjoram and the harvest interval, in the winter transplant, showed an increase in masses as the intervals became longer, resulting in the highest accumulated mass production at the 90-day interval for all variables (Figure 3). These results are similar to those obtained in the summer transplant and show the better productive capacity of plants with a lower cutting intensity.

The production of marjoram is directly influenced by the harvest interval, and it is more appropriate to adopt longer periods between harvests, regardless of the conditions of plant transplant. This was observed in the present study, in which two independent experiments were conducted, with transplants under different climatic conditions (Figure 1) and seedlings from different sources, but with similar productive responses.

There is a lack of recent information on the best harvest interval for the production of marjoram mass. However, a similar response to that found in present study was reported for another seasoning species, rosemary, for which the largest accumulation of dry matter of the aerial part occurred at a longer harvest interval (May et al., 2010). According to these authors, when medicinal plants are harvested at shorter intervals, their recovery period is shorter, which can reduce their productivity.

Since leaves are the most important part of condiment species (Ibrahim et al., 2012), either for fresh consumption as seasoning or for oil extraction, the most important result for recommendations is the matter mass of leaves. However, it is also fundamental to understand the response of the whole plant to these management conditions.

Although the largest production of fresh matter of leaves occurred at the intervals of 60 and 90 days in the summer transplant and of 72 and 90 days in the winter transplant, it should be taken into account that the natural cycle of marjoram lasts about 60 days (Pereira $\&$ Santos, 2013). During this period, the flowering of this species occurs, meaning that, at intervals longer than 60 days, the plant begins its process of natural senescence. Therefore, with no difference between these intervals, it is recommended to use the interval of 60 days for the summer transplant and of 72 days for the winter transplant. These intervals allow the accumulation of a greater phytomass at the end of the cycle, resulting in younger and healthier plants at harvest, with less senescent leaves, and also facilitate management and reduce operating costs due to the lower volume of plants (May et al., 2010). 
Despite these results, additional studies are still necessary to verify the most appropriate interval to produce marjoram for oil production, since better conditions for a higher production of mass could be inappropriate for a higher production and better quality of essential oil.
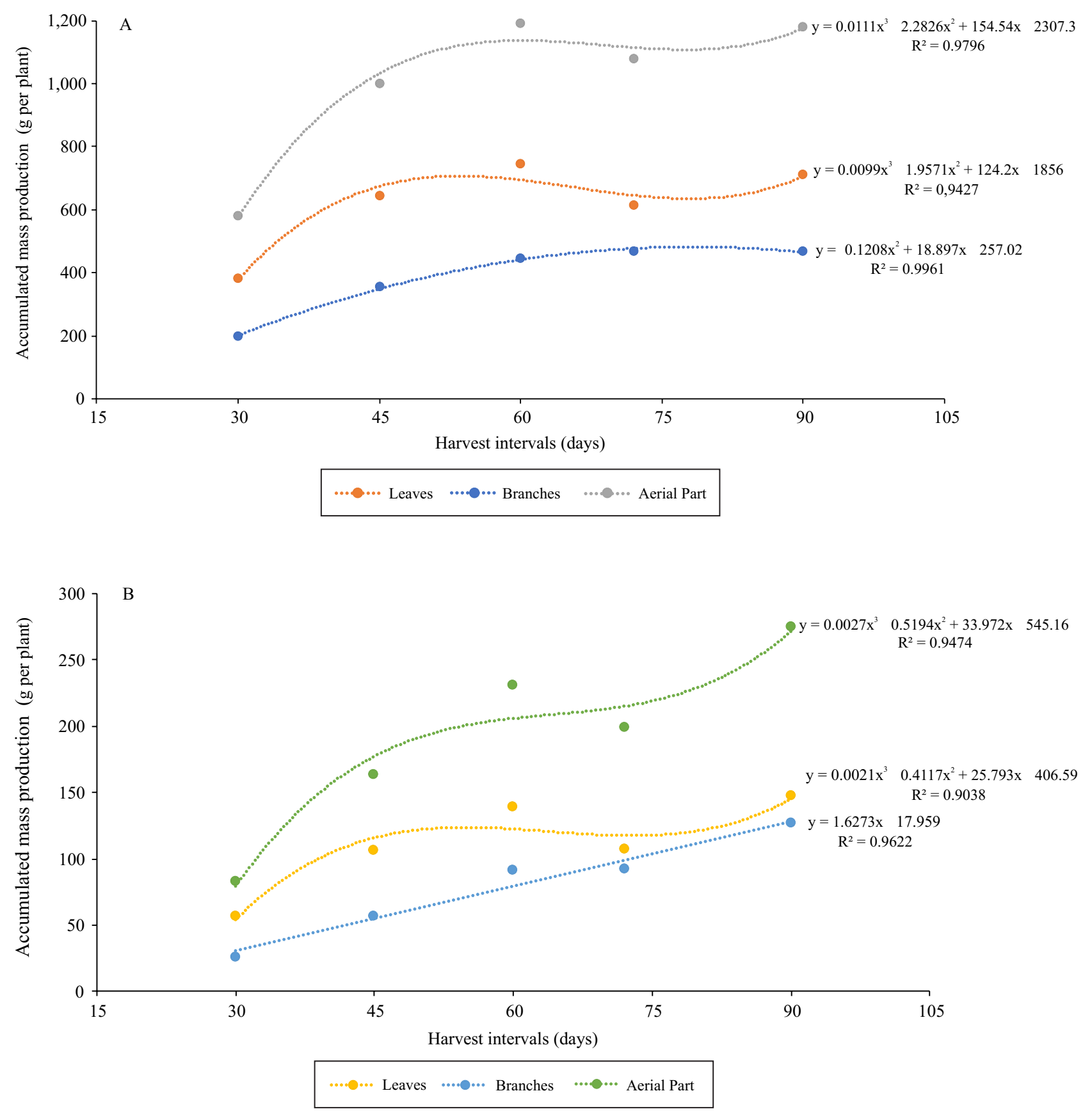

Figure 2. Regression analysis of accumulated mass production at harvest intervals in the summer transplant. A, fresh matter masses of leaves, branches, and aerial part; and B, dry matter masses of leaves, branches, and aerial part. 

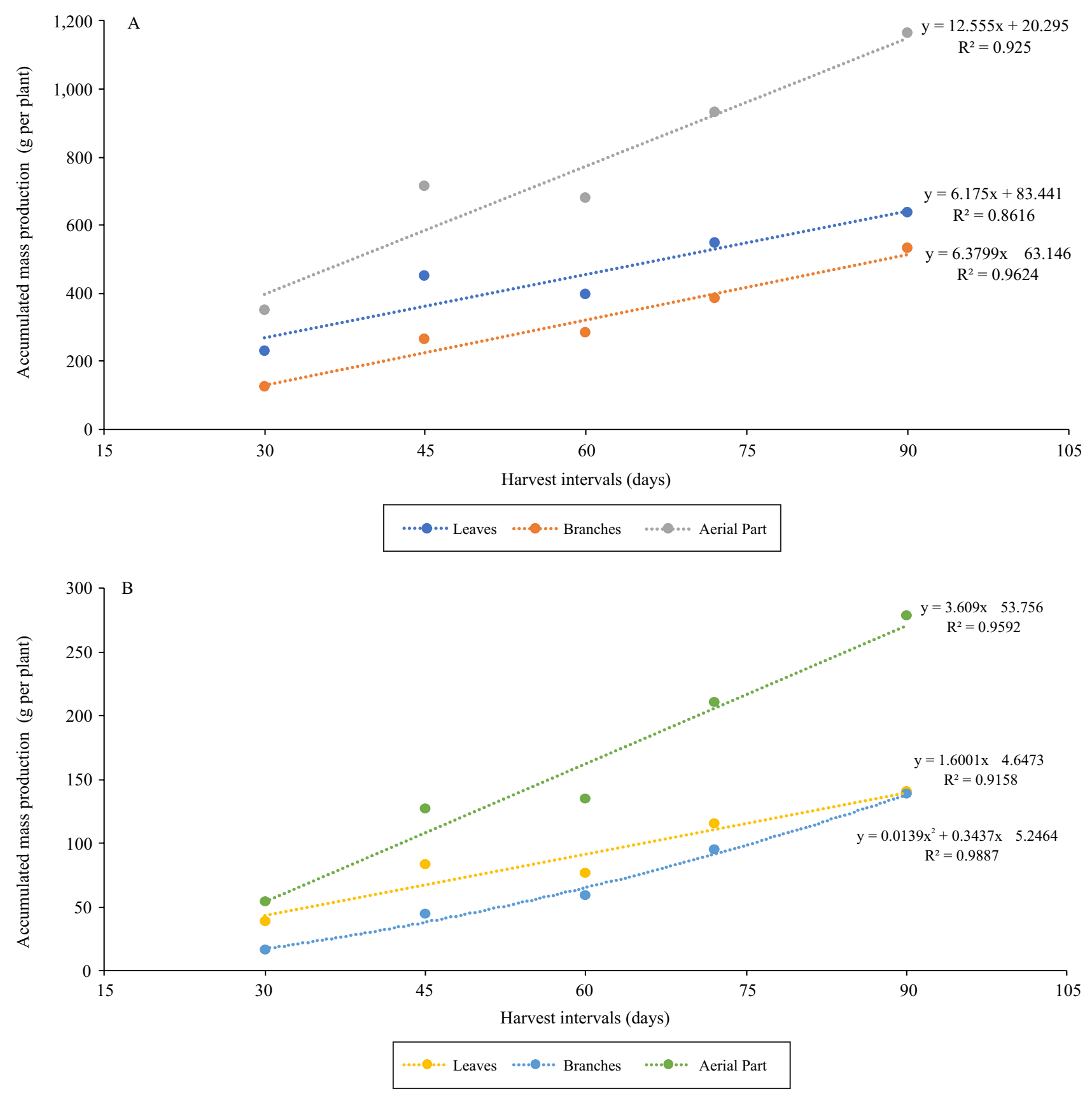

Figure 3. Regression analysis of accumulated mass production at harvest intervals in the winter transplant. A, fresh matter masses of leaves, branches, and aerial part; and B, dry matter masses of leaves, branches, and aerial part.

\section{Conclusions}

1. For the summer transplant, harvesting at 60-day intervals is appropriate for the phytomass production of marjoram (Origanum majorana) leaves.

2. For the winter transplant, harvesting at 72-day intervals is appropriate for the phytomass production of marjoram leaves.

\section{Acknowledgments}

To Conselho Nacional de Desenvolvimento Científico e Tecnológico $(\mathrm{CNPq}$, process number $304652 / 2017-2$ ), for scholarship to the authors; and to Coordenação de Aperfeiçoamento de Pessoal de Nível Superior (Capes), for financing, in part, this study (Finance Code 001). 


\section{References}

EQUIPE ESTATCAMP. Software action. São Carlos: EstatcampConsultoria em estatística e qualidade, 2014.

FERREIRA, D.F. Sisvar: a guide for its bootstrap procedures in multiple comparisons. Ciência e Agrotecnologia, v.38, p.109-112, 2014. DOI: https://doi.org/10.1590/S1413-70542014000200001.

IBRAHIM, R.; HADDAD, N.; HADDADIN, M.; ABU SALAH, K. Evaluation of agro-morphological characters and oil percentage of Origanum syriacum L. and Origanum majorana L. at three dates of initial cutting. Jordan Journal of Agricultural Sciences, v.8, p.33-45, 2012.

JELALI, N.; DHIFI, W.; CHAHED, T.; MARZOUK, B. Salinity effects on growth, essential oil yield and composition and phenolic compounds content of marjoram (Origanum majorana L.) leaves. Journal of Food Biochemistry, v.35, p.1443-1450, 2011. DOI: https://doi.org/10.1111/j.1745-4514.2010.00465.x.

JOSHI, B.; LEKHAK, S.; SHARMA, A. Antibacterial property of different medicinal plants: Ocimum sanctum, Cinnamomum zeylanicum, Xanthoxylum armatum and Origanum majorana. Kathmandu University Journal of Science, Engineering and Technology, v.5, p.143-150, 2009. DOI: https://doi.org/10.3126/ kuset.v5i1.2854.

LEEJA, L.; THOPPIL, J.E. Antimicrobial activity of methanol extract of Origanum majorana L. (sweet marjoram). Journal of Environmental Biology, v.28, p.145-146, 2007.

LUZ, J.M.Q.; RESENDE, R.F. de; SILVA, S.M.; SANTANA, D.G. de; CAMILO, J. da S.; BLANK, A.F.; HABER, L.L. Produção de óleo essencial de Ocimum basilicum L. em diferentes épocas, sistemas de cultivo e adubações. Boletín Latinoamericano y del Caribe de Plantas Medicinales y Aromáticas, v.13, p.69-80, 2014.

MAIA, J.T.L.S.; LEITE, R.S.; FERES, C.I.M. e A.; JONES, K.M. Plantas medicinais em hidroponia: uma revisão de literatura. Revista Bionorte, v.3, p.31-41, 2014.

MAMBRI, A.P.S.; ANDRIOLO, J.L.; MANFRON, M.P.; PINHEIRO, S.M.G.; CARDOSO, F.L.; NEVES, M.G. Crescimento, rendimento e composição do óleo volátil de lavanda em cultivo sem solo em três épocas sucessivas de colheita com e sem sombreamento. Horticultura Brasileira, v.36, 2018. Não paginado.
MAY, A.; BOVI, O.A.; MAIA, N.B.; MORAES, A.R.A. de; PINHEIRO, M.Q.; MARIO, M. de. Influência do intervalo entre cortes sobre a produção de biomassa de duas espécies de capim limão. Horticultura Brasileira, v.26, p.379-382, 2008. DOI: https://doi.org/10.1590/S0102-05362008000300017.

MAY, A.; SUGUINO, E.; MARTINS, A.N.; BARATA, L.E.S.; PINHEIRO, M.Q. Produção de biomassa e óleo essencial de alecrim (Rosmarinus officinalis L.) em função da altura e intervalo entre cortes. Revista Brasileira de Plantas Medicinais, v.12, p.195-200, 2010. DOI: https://doi.org/10.1590/S151605722010000200011.

MOSSA, A.T.H.; NAWWAR, G.A.M. Free radical scavenging and antiacetylcholinesterase activities of Origanum majorana L. essential oil. Human \& Experimental Toxicology, v.30, p.15011513, 2011. DOI: https://doi.org/10.1177/0960327110391686.

PEREIRA, R. de C.A.; SANTOS, O.G. dos. Plantas condimentares: cultivo e utilização. Fortaleza: Embrapa Agroindústria Tropical, 2013. 55p. (Embrapa Agroindústria Tropical. Documentos, 161).

ROBY, M.H.H.; SARHAN, M.A.; SELIM, K.A.-H.; KHALEL, K.I. Evaluation of antioxidant activity, total phenols and phenolic compounds in thyme (Thymus vulgaris L.), sage (Salvia officinalis L.), and marjoram (Origanum majorana L.) extracts. Industrial Crops and Products, v.43, p.827-831, 2013. DOI: https://doi.org/10.1016/j.indcrop.2012.08.029.

SABIR, N.; SINGH, B. Protected cultivation of vegetables in global arena: a review. Indian Journal of Agricultural Sciences, v.83, p.123-135, 2013.

SABRA, A.S.; ASTATKIE, T.; ALATAWAY, A.; MAHMOUD, A.A.; GENDY, A.S.H.; AHL, H.A.H.S.-A.; TKACHENKO, K.G. Response of biomass development, essential oil, and composition of Plectranthus amboinicus (Lour.) Spreng. to irrigation frequency and harvest time. Chemistry \& Biodiversity, v.15, e1800005, 2018. DOI: https://doi.org/10.1002/cbdv.201800005.

SANTOS, L.L.; SEABRA JUNIOR, S.; NUNES, M.C.M. Luminosidade, temperatura do ar e do solo em ambientes de cultivo protegido. Revista de Ciências Agro-Ambientais, v.8, p.83-93, 2010.

SELIM, S.M.; EBTSAM, M.M.A.; TAWFIK, M.S.H.; ABOUSREEA, A.I. Effect of sowing date, sow spacing and bio-fertilizer on yield and oil quality of fennel plant (Foeniculum vulgare, Mill.). Australian Journal of Basic and Applied Sciences, v.7, p.882-894, 2013. 